\title{
DETERMINATION OF ASPARTATE KINASE ACTIVITY IN MAIZE TISSUES
}

\author{
Renato Rodrigues Ferreira ${ }^{1}$; Ariane Vendemiatti²; Priscila Lupino Gratão²; Peter John Lea ${ }^{3}$; \\ Ricardo Antunes Azevedo ${ }^{2 *}$ \\ ${ }^{1}$ UNICAMP/IB - Depto. de Genética e Evolução, C.P. 6109 - 13083-970 - Campinas, SP - Brasil. \\ ${ }^{2}$ USP/ESALQ - Depto. de Genética, C.P. 83 - 13418-900 - Piracicaba, SP - Brasil. \\ ${ }^{3}$ Lancaster University - Dept. Biological Sciences, LA1 4YQ - Lancaster - United Kingdom. \\ *Corresponding author < raazeved@esalq.usp.br>
}

\begin{abstract}
Lysine, threonine, methionine and isoleucine are synthesized from aspartate in a branched pathway in higher plants. Aspartate kinase plays a key role in the control of the aspartate pathway. The enzyme is very sensitive to manipulation and storage and the hydroxamate assay normally used to determine aspartate kinase activity has to be altered according to the plant species and tissue to be analyzed. We have optimized the assay for the determination of aspartate kinase in maize plants callus cell cultures. Among all the assay parameters tested, the concentration of ATP/Mg and temperature were critical for enzyme activity. In the case of temperature, $35^{\circ} \mathrm{C}$ was shown to be the optimum temperature for aspartate kinase activity. Key words: aspartate pathway, maize, lysine, threonine, methionine
\end{abstract}

\section{DETERMINAÇÃO DA ATIVIDADE DE ASPARTATO QUINASE EM TECIDOS DE MILHO}

\begin{abstract}
RESUMO: Lisina, treonina, metionina e isoleucina são derivados do aspartato. Aspartato quinase tem um papel chave no controle da via metabólica do aspartato. A enzima é muito sensível à manipulação e armazenagem e o ensaio enzimático do hidroxamato que é normalmente utilizado para determinar a atividade da aspartato quinase deve ser alterado de acordo com a espécie de planta e tecido vegetal a ser analisado. Nós otimizamos o ensaio para a determinação da atividade da aspartato quinase em culturas celulares de calos de milho. Entre os vários parâmetros testados do ensaio, a concentração de ATP/Mg e temperatura foram críticos para atividade enzimática. No caso da temperatura, $35^{\circ} \mathrm{C}$ foi a temperatura ótima para atividade da aspartato quinase.

Palavras-chave: via do aspartato, milho, lisina, treonina, metionina
\end{abstract}

\section{INTRODUCTION}

Nitrogen is essential for plant growth and development, and is often a limiting factor for high productivity (Mauad et al., 2003; Medici et al., 2004). Amino acids are the major nitrogen containing compounds of plants and are the building-blocks of proteins (Helm et al., 2004). The essential amino acids lysine, threonine, methionine and isoleucine are derived from aspartic acid in a strongly regulated metabolic pathway (Lefèvre et al., 2002; Toro et al., 2003).

Aspartate kinase (AK, EC 2.7.2.4) is the first enzyme of the aspartate family pathway and is required for the synthesis of the amino acid end products (Azevedo et al., 1997). AK catalyses the phosphorylation of aspartate to form b-aspartyl phosphate, with the accompanying hydrolysis of ATP (Azevedo, 2002). AK has been identified, isolated and partially purified from a wide range of economically important crops, including some high-lysine mutants (Azevedo et al., 2003; 2004a; 2000b; Ferreira et al., 2004). Several lines of evidence have indicated that plants generally possess at least two or three different isoenzymes of AK. The distribution of the AK isoenzymes may vary among the plant species. In general, the lysine-sensitive AK isoenzyme has been shown to represent approximately $80 \%$ of the total AK activity in almost all plant species tested so far (Azevedo \& Lea, 2001). Homoserine dehydrogenase (HSDH, EC 1.1.1.3) catalyzes the first reaction that is unique for threonine, methionine, and isoleucine biosynthesis, which converts aspartate semialdehyde into homoserine in the presence of the coenzymes NADH or NADPH (Azevedo et al., 1997). Two isoenzymes of HSDH, one sensitive and the other resistant to threonine inhibition have been detected in plants (Azevedo \& Lea, 2001). The existence of a bifunctional AK-HSDH isoenzyme sensitive to feedback inhibition by threonine, has been confirmed by the analysis of genes encoding the enzymes from several plant species (Muehlbauer et al., 1994). 
We have previously studied AK from a wide range of plant species and noted a considerable variability in its action and stability during isolation, purification and characterization. Maize is one of the major crops worldwide (Pinto et al., 2003) and in this report we have analyzed AK from maize tissues callus cell cultures and optimized the assay for the determination of AK activity from maize. Due to the nature of such a study, the experiments were carried out twice and the means of three repetitions for each assay were taken into consideration. As each optimal assay condition was established, it was immediately adopted as standard in subsequent experiments.

\section{MATERIAL AND METHODS}

Callus tissue culture of the Cat100-1 (cateto) maize inbred line was used. Seeds of the Cat100-1 inbred line were kindly donated by the Department of Genetics and Evolution of the State University of Campinas, Brazil, and used to produce the callus culture used in this research.

For growth cycle analysis in solid medium, $50 \mathrm{mg}$ of callus grown for 30 days on M09-2 solid medium (Prioli \& Söndahl, 1989) were transferred to Petri dishes containing $25 \mathrm{~mL}$ of fresh M09-2 medium. The cultures were incubated in the dark at $31 \pm 1^{\circ} \mathrm{C}$ (standard conditions) and callus from ten Petri dishes were harvested and combined at two days intervals for 35 days of culture. The fresh weights were recorded and the callus stored at $-80^{\circ} \mathrm{C}$ for future AK assays. The experiment was repeated three times under identical conditions.

The growth cycle analysis for callus growing in liquid medium was carried out using the same source of cells. Cat100-1 calli, grown for 30 days on solid M09-2 medium, were transferred to conical flasks $(0.7 \mathrm{~g}$ of callus/ $125 \mathrm{~mL}$ conical flasks) containing $50 \mathrm{~mL}$ of freshly prepared M09-2 medium. The cultures were placed on an orbital shaker at $150 \mathrm{rpm}$ for 20 days under standard conditions. The growth of the cultures was measured by harvesting callus from three flasks together at two days intervals. The fresh weight of the suspension was determined by the collection of small and large cell aggregates on pre-weighted filter paper (Whatman GFA- ${ }^{\circ} 1$ filter, 9 $\mathrm{cm}$ ), draining under a slight vacuum and weighing again. The cells were stored frozen at $-80^{\circ} \mathrm{C}$ for further $\mathrm{AK}$ assay. The experiment was repeated twice.

All procedures were carried out at $4^{\circ} \mathrm{C}$ unless stated otherwise. Samples, fresh or frozen at $-80^{\circ} \mathrm{C}$, were ground with liquid nitrogen in a pestle and mortar with 5:1 (v/w) extraction buffer ( $50 \mathrm{mmol} \mathrm{L}^{-1}$ Tris/ $\mathrm{HCl} \mathrm{pH} 7.4$ with $50 \mathrm{mmol} \mathrm{L}^{-1} \mathrm{KCl}, 2 \mathrm{mmol} \mathrm{L}^{-1} \mathrm{~L}$-lysine, $2 \mathrm{mmol} \mathrm{L}^{-1}$ L-threonine, 1 mmol L ${ }^{-1}$ DTT, $0.1 \mathrm{mmol} \mathrm{L}^{-1}$ phenylmethylsulphonyl fluoride (PMSF), $0.1 \mathrm{mmol} \mathrm{L}^{-1}$ EDTA, $0.1 \mathrm{mmol} \mathrm{L}^{-1} \mathrm{~N}$-ethylmaleimide, $20 \%(\mathrm{v} / \mathrm{v})$ ethanediol, 5\% (w/v) PVP) and the extract filtered through several layers of gauze. The filtered extracts were centrifuged at 16,000 rpm for $30 \mathrm{~min}$. to remove cell debris. The supernatants were collected and brought to $60 \%$ saturation with ammonium sulphate by stirring for $1 \mathrm{~h}$. The protein pellets were collected by centrifugation at 16,000 rpm for $30 \mathrm{~min}$. and resuspended with 0.1-1 mL of $100 \mathrm{mmol} \mathrm{L}^{-1}$ Tris/HCl (pH 7.4) buffer containing $50 \mathrm{mmol} \mathrm{L}^{-1} \mathrm{KCl}, 0.1 \mathrm{mmol} \mathrm{L}{ }^{-1}$ L-lysine, 0.1 mmol L ${ }^{-1}$ L-threonine, 1 mmol L ${ }^{-1}$ DTT and $10 \%(\mathrm{v} / \mathrm{v})$ ethanediol. The extracts were desalted on Sephadex G25 columns (variable sizes: $1-5 \mathrm{~mL}$ ) equilibrated with the same buffer.

AK activity was assayed routinely in a final volume of $500 \mathrm{~mL}$ as described by Bonner \& Lea (1990) with modifications according to the results obtained in this investigation. The assay mixture comprised $100 \mu \mathrm{L}$ $100 \mathrm{mmol} \mathrm{L}^{-1}$ Tris - HCl (pH 7.4) containing $1 \mathrm{mmol} \mathrm{L}^{-1}$ DTT and 20\% (v/v) ethanediol, $100 \mu \mathrm{L} 500 \mathrm{mmol} \mathrm{L}^{-1}$ aspartic acid (pH 7.4), $50 \mu \mathrm{L} 125 \mathrm{mmol} \mathrm{L}^{-1}$ magnesium sulphate, $50 \mu \mathrm{L} 200 \mathrm{mmol} \mathrm{L}^{-1}$ ATP (pH 7.4), $50 \mu \mathrm{L} 4 \mathrm{~mol}$ $\mathrm{L}^{-1}$ hydroxylamine ( $\mathrm{pH} 7.4$ ), $100 \mu \mathrm{L} \mathrm{H}_{2} \mathrm{O}$ and $50 \mu \mathrm{L}$ of enzyme extract. The assay was started by the addition of $50 \mu \mathrm{L}$ ATP and incubated at $35^{\circ} \mathrm{C}$ for $30 \mathrm{~min}$. The assay was terminated by the addition of $500 \mu \mathrm{L}$ of $\mathrm{FeCl}_{3}$ reagent $\left[670 \mathrm{mmol} \mathrm{L}^{-1} \mathrm{FeCl}_{3}, 370 \mathrm{mmol} \mathrm{L}^{-1} \mathrm{HCl}\right.$ and $20 \%$ (w/v) TCA]. After centrifugation for $10 \mathrm{~min}$ at 10,000 rpm, to remove precipitated protein, the absorbance of the supernatant was measured at $505 \mathrm{~nm}$. Controls containing $10 \mu \mathrm{L} 10 \mathrm{mmol} \mathrm{L}^{-1}$ lysine, $10 \mu \mathrm{L} 10 \mathrm{mmol} \mathrm{L}^{-1}$ threonine and $10 \mu \mathrm{L} 10 \mathrm{mmol} \mathrm{L}^{-1}$ lysine plus $10 \mathrm{mmol} \mathrm{L}^{-1}$ threonine were normally included to ensure that the activity measured was due to AK and to identify the isoenzymes sensitive to lysine and threonine. Three replications (different extracts) were carried out for each assay.

The components of the assay were examined to determine the optimum conditions for the measurement of AK activity from Cat 100-1 cell suspension cultures. The experiments were carried out twice and the mean of three repetitions for each assay considered. As each optimal assay condition was determined, it was immediately adopted as standard in subsequent experiments.

The magnesium sulphate and ATP components of the assay were tested by varying their concentration and testing them separately and some in combination. Magnesium sulphate was tested at 5, 10, 12.5, 20, 25 and $50 \mathrm{mmol} \mathrm{L}^{-1}$ while ATP was tested at 10, 20, 40 and 80 mmol L ${ }^{-1}$. The effect of changing hydroxylamine concentrations in the assay was determined by incubating 100 $\mu \mathrm{L}$ of the AK samples in the presence of 50, 100, 200, 300, 400, 500 and $600 \mathrm{mmol} \mathrm{L}^{-1}$ hydroxylamine at $30^{\circ} \mathrm{C}$. Identical assay mixtures containing $100 \mu \mathrm{L}$ of the $\mathrm{AK}$ sample were incubated in different water baths each set to a different temperature: $25,28,30,35,40$ and $50^{\circ} \mathrm{C}$ for a 60 min incubation time. The effect of $\mathrm{pH}$ on the $\mathrm{AK}$ 
activity was tested. For this experiment, new stock solutions with the $\mathrm{pH}$ adjusted were prepared with the exception of the magnesium sulphate stock solution. The assay was run with $100 \mu \mathrm{L}$ of the AK sample for $60 \mathrm{~min}$ at $35^{\circ} \mathrm{C}$. Variations on the $\mathrm{pH}$ of $6.8,7.1,7.4,7.7$ and 8.0 were tested. Variations of the concentration of the substrate (25, 50, 100 and $200 \mathrm{mmol} \mathrm{L}^{-1}$ aspartic acid) for AK were tested. $\mathrm{KCl}$ concentration $(0,100,200,300,400$ and $500 \mathrm{mmol} \mathrm{L}^{-1}$ ) in the assay mixture was tested. Concentration of plant extract $(25,50,75,100,125$ and 150 $\mu \mathrm{L}$ ) and time of incubation (15 min to $180 \mathrm{~min}$ ) were also tested on AK activity. Lysine and threonine were added at 1, 2, 5 and $10 \mathrm{mmol} \mathrm{L}^{-1}$ to the assay mixture replacing the water fraction $(50 \mu \mathrm{L})$, to test their inhibitory effect on AK activity.

The protein concentrations of all samples employed in this study were determined by the method of Bradford (1976), using bovine serum albumin as a standard. The data analysis was carried out as a descriptive statistics of means and standard errors of means to indicated data dispersion.

\section{RESULTS AND DISCUSSION}

Lysine and threonine, which are in low concentrations in cereal seeds are derived from aspartate (Lefèvre et al., 2002; Toro et al., 2003). The in vitro manipulation of AK has proved to be difficult and in order to isolate and characterize the enzyme from different plant tissues, the assay used to determine enzyme activity has to be efficient. Cell suspension cultures have proved to be the best source for the purification of AK from maize, as they exhibit high levels of activity. Since AK is normally present in low activity in higher plant tissues (Azevedo et al., 1997), the choice of the method to assay AK activity is critical.

Figure 1A presents the growth curve of Cat1001 callus grown in solid medium for 30 days. During the early stages of growth there was a peak of AK activity that reached a maximum after 13 days in culture (Figure 1B), however, the AK activity was not high (0.0063 nkat $\mathrm{mg}^{-1}$ protein). AK activity was significantly inhibited by $2 \mathrm{mmol} \mathrm{L}^{-1}$ L-lysine, whereas L-threonine did not pro-
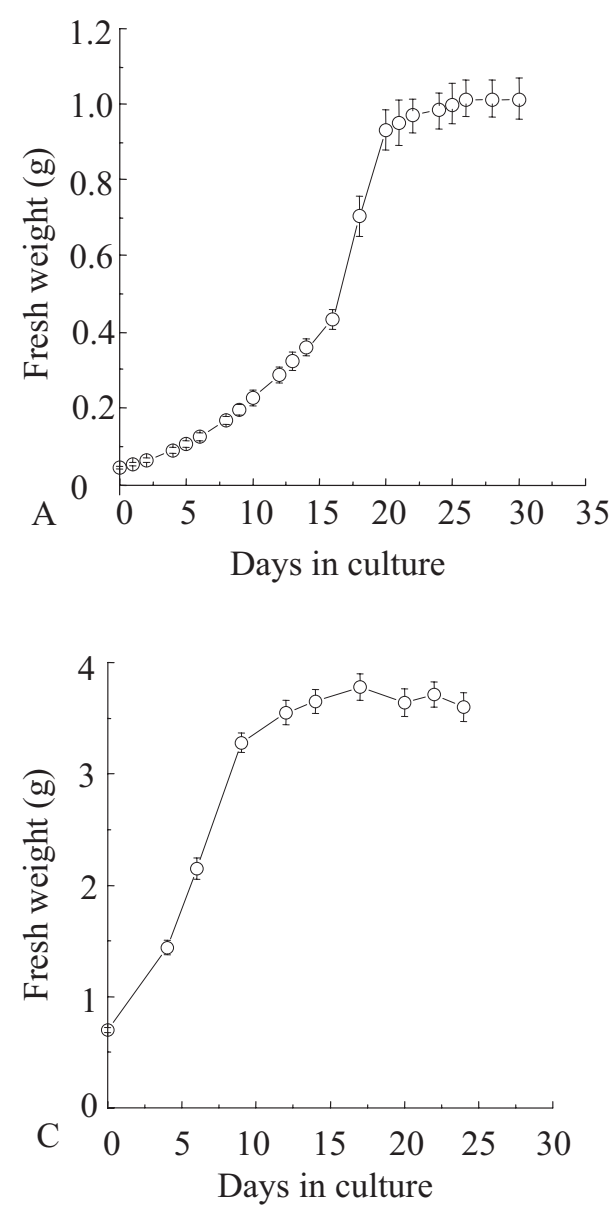
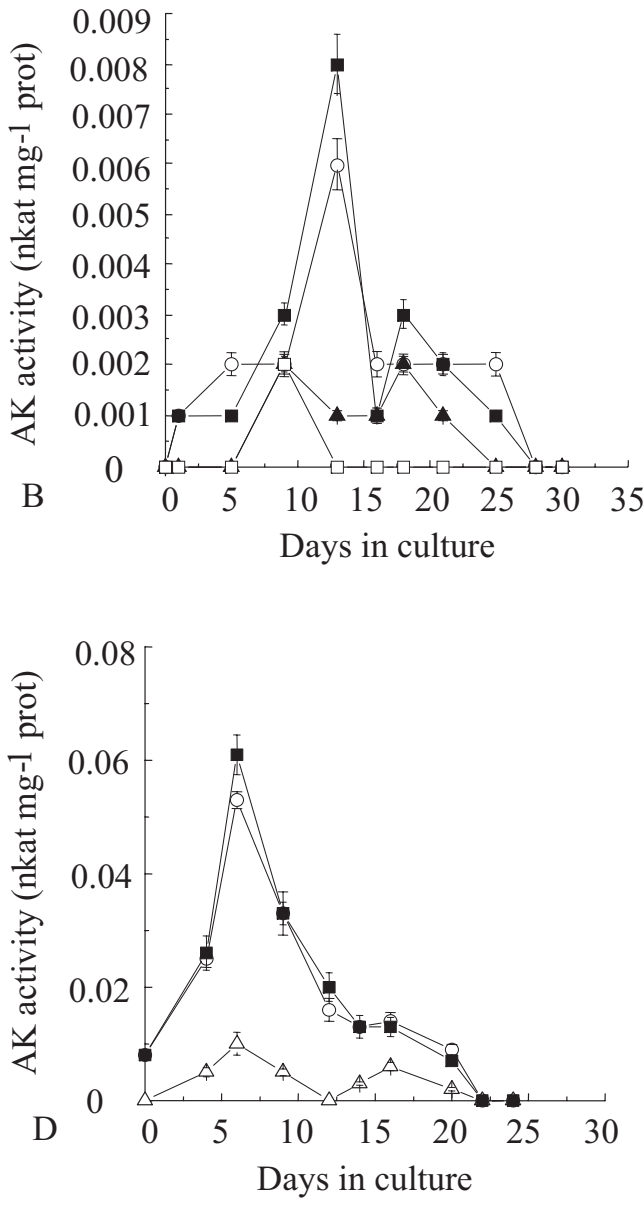

Figure 1 - Growth cycle analysis of Cat100-1 callus tissue culture in solid (A and B) and liquid (C and D) M09-2 medium. A) Growth of the culture (fresh weight) during a 30 days period. B) AK control activity (O) and in the presence of $2 \mathrm{mmol} \mathrm{L}^{-1}$ threonine ( $\left.\boldsymbol{\square}\right)$, $2 \mathrm{mmol} \mathrm{L}^{-1}$ lysine $(\boldsymbol{\Delta})$ and $2 \mathrm{mmol} \mathrm{L}^{-1}$ lysine plus threonine ( $\square$ ). C) Growth of the culture (fresh weight) during a 25 days period. D) AK control activity (O) and in the presence of $2 \mathrm{mmol} \mathrm{L}^{-1}$ threonine ( $\left.\boldsymbol{\square}\right)$ and $2 \mathrm{mmol} \mathrm{L}^{-1}$ lysine $(\triangle)$. 
duce any inhibitory effect on AK activity at $2 \mathrm{mmol} \mathrm{L}^{-1}$. These results characterised the peak of AK activity as sensitive to lysine, however the addition of lysine and threonine (2 mmol L${ }^{-1}$ each) resulted in a stronger inhibition of activity than lysine alone. All these results are also true for the second stage of fast growth, although the AK activity was lower (0.0024 nkat $\mathrm{mg}^{-1}$ protein).

AK activity was also studied in Cat100-1 callus grown in M09-2 liquid medium (Figure 1C, D). The result clearly showed that the AK activity was much higher than in callus grown in solid medium (0.053 as compared to 0.0063 nkat $\mathrm{mg}^{-1}$ protein) (Figure 1D). The stage of fast growth of the culture started on the fourth day with maximum growth around the ninth day. This period of growth produced a peak of AK activity which reached a maximum after six days of culture. This AK peak was also inhibited by lysine $\left(2 \mathrm{mmol} \mathrm{L}^{-1}\right)$, but not by threonine at the same concentration, indicating that the activity was due to a lysine-sensitive AK isoenzyme. The production of tissue in comparison with the system using solid medium was twice as effective and there was also a considerable reduction in time (six days for liquid cultures to 13 days for solid cultures) to reach the maximum AK activity. Furthermore, in one single flask a much higher volume of cells could be grown. The main technical advance of this system was that cells were in contact with the medium, growing at approximately the same rate. The liquid culture system can be much more efficient for producing tissue and higher AK activity. Therefore Cat100-1 callus grown in liquid medium was used for the partial purification of AK.

Two assays have been used to measure AK activity; the coupled assay and the hydroxamate assay. The coupled assay has been used particularly when kinetic analyses of AK were being carried out (Dotson et al., 1990), whereas the hydroxamate assay has been used commonly during purification procedures or for quick determinations (Dotson et al., 1989). Both methods are susceptible to interference from other enzyme activities that may be present in the tissue extracts (Davies \& Miflin, 1977). Therefore, to ensure that the absorbance produced (or what proportion of the absorbance measured) is due to AK activity, controls must be added to the assay (Bonner \& Lea, 1990). Lysine and threonine can be used to inhibit the lysine and threonine sensitive forms of AK, respectively, and a blank containing all components of the assay mixture minus aspartic acid must be used. These, plus a very good analysis of the components included in the assay mixture must be considered when designing an accurate, sensitive and specific assay for AK.

Research involving the purification of AK requires quick identification of AK activity. The hydroxamate assay is very simple, quick and reproducible, therefore this assay was chosen and used in all experiments. The hydroxamate assay described by Bonner \& Lea (1990) was used initially to measure AK activity in the experiments carried out. The components and assay conditions were tested and some important variations were observed (Figure 2), such as those related to the assay temperature and the ATP/magnesium sulphate concentrations (Figure 2B, E, F), whereas for all other parameters tested the commonly used concentrations appear to be at adequate levels for AK activity measurements.

The presence of ATPases in the plant extract could transform ATP into ADP consequently reducing the availability of this component in the assay mixture for AK, with possible underestimation of enzyme activity, especially when the activity of ATPase is high. Higher concentrations of ATP could be added, however the cost would be considerably higher. Moreover, the ATP/magnesium ratio would have to be reconsidered for each extract.

Figure 2D shows the results obtained by varying the ATP concentration in the assay. It would appear that with the maize extracts employed, that there is little interference from ATPase on AK activity, since the sample in which the concentration of ATP was doubled, showed practically the same absorbance as the assay mixture containing the initial concentration of ATP. This result is important, since this partially purified sample represents the first step of purification. Concentrations of magnesium and ATP in the assay have been tested in many higher plants (Aarnes \& Rognes, 1974; Davies \& Miflin, 1977; Bonner \& Lea, 1990). Figure 2E shows the effect of different concentrations of magnesium sulphate with a constant $20 \mathrm{mmol} \mathrm{L}^{-1}$ ATP concentration, while Figure $2 \mathrm{~F}$ presents the effect of the varying the concentration of ATP with a constant $25 \mathrm{mmol} \mathrm{L}^{-1}$ magnesium sulphate concentration. The results show that a decrease from

Table 1- Effect of different concentrations of magnesium sulphate and ATP on AK activity from callus cell cultures.

\begin{tabular}{lcccc}
\hline \multirow{2}{\mathrm{MgSO}_{4}}{$\begin{array}{c}\text { AK O.D. }(505 \mathrm{~nm}) \\
\left(\mathrm{mmol} \mathrm{L}^{-1}\right)\end{array}$} & \multicolumn{4}{c}{ ATP $\left(\mathrm{mmol} \mathrm{L}^{-1}\right)$} \\
\cline { 2 - 5 } & 10 & 12.5 & 20 & 25 \\
\hline 10 & $0.145 \pm 0.011$ & $0.148 \pm 0.006$ & $0.157 \pm 0.005$ & $0.141 \pm 0.009$ \\
12.5 & $0.154 \pm 0.008$ & $0.160 \pm 0.010$ & $0.183 \pm 0.007$ & $0.170 \pm 0.008$ \\
20 & $0.142 \pm 0.009$ & $0.150 \pm 0.008$ & $0.154 \pm 0.007$ & $0.150 \pm 0.012$ \\
25 & $0.131 \pm 0.006$ & $0.138 \pm 0.008$ & $0.138 \pm 0.009$ & $0.133 \pm 0.010$ \\
\hline
\end{tabular}

Sci. Agric. (Piracicaba, Braz.), v.62, n.2, p.184-189, Mar./Apr. 2005 

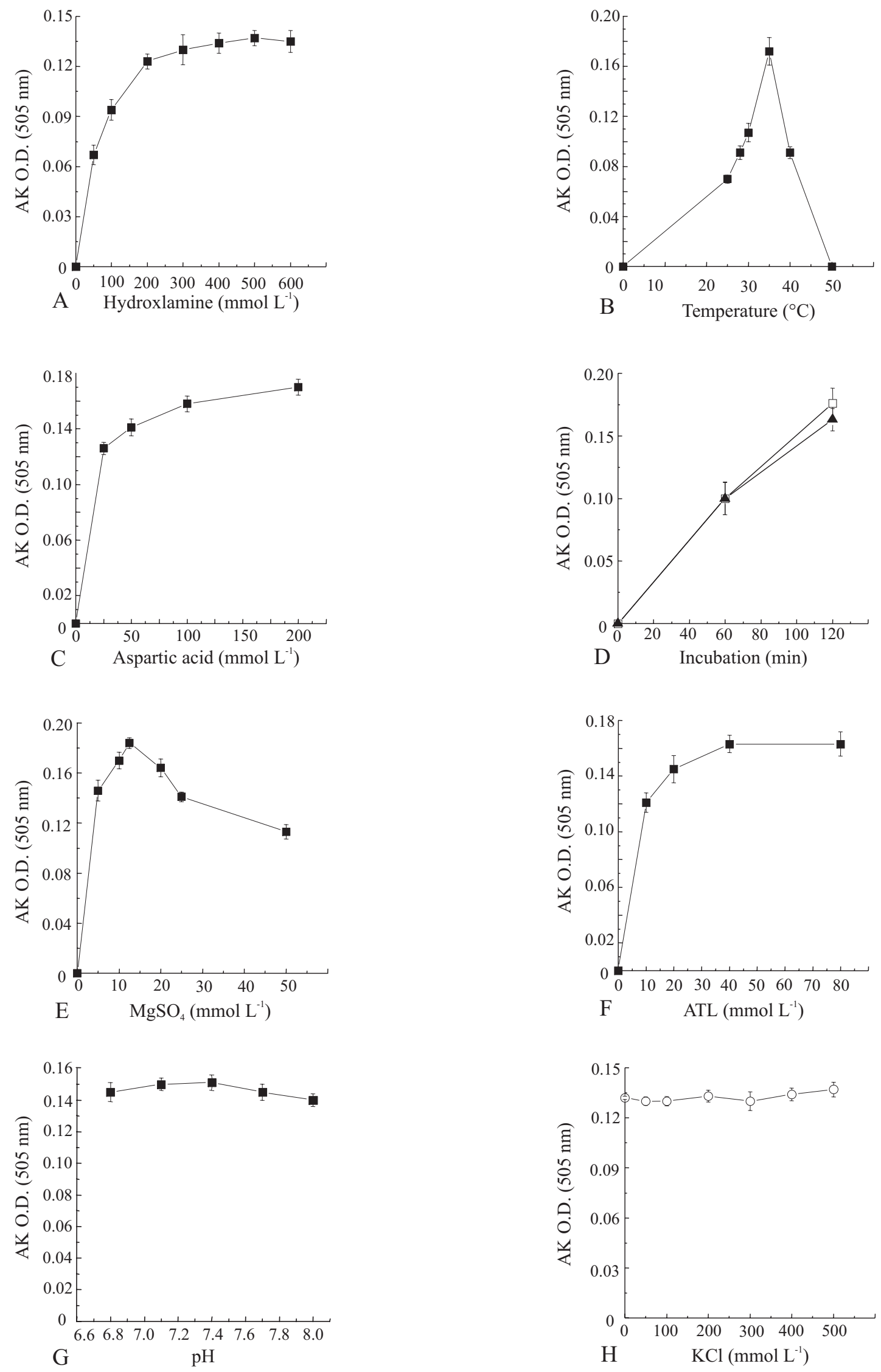

Figure 2 - The effect of (A) hydroxylamine concentration, (B) temperature of incubation, (C) aspartate concentration, (D) incubation time, (E) $\mathrm{MgSO}_{4}$ concentration, (F) ATP concentration, $(\mathrm{G}) \mathrm{pH}$ and $(\mathrm{H}) \mathrm{KCl}$ concentration on AK activity from callus cell cultures.

Sci. Agric. (Piracicaba, Braz.), v.62, n.2, p.184-189, Mar./Apr. 2005 
$25 \mathrm{mmol} \mathrm{L}^{-1}$ to $12.5 \mathrm{mmol} \mathrm{L}^{-1}$ magnesium sulphate considerably increased the AK activity. Such a result was not observed following variation of the ATP concentration (Figure 2F). Both components were further tested varying their concentrations (Table 1). The differences noted when changing the magnesium sulphate concentration was once more critical and a combination of $12.5 \mathrm{mmol} \mathrm{L}^{-1}$ magnesium sulphate and $20 \mathrm{mmol} \mathrm{L}^{-1}$ ATP produced the highest increase (38\%) in AK activity in relation to the standard $20 \mathrm{mmol} \mathrm{L}^{-1}$ magnesium sulphate and $20 \mathrm{mmol} \mathrm{L}^{-1}$ ATP suggested in the literature. These results contrast with the data described previously for barley (Shewry \& Miflin, 1977) and pea seedlings (Aarnes \& Rognes, 1974), in which a small excess of magnesium in relation to ATP was required for higher AK activity. In carrot cell suspension cultures (Davies \& Miflin, 1977) and maize seedlings (Cheshire \& Miflin, 1975) equimolar levels were required. Bonner \& Lea (1990) reported an optimum concentration of $25 \mathrm{mmol} \mathrm{L}^{-1}$ magnesium sulphate and $20 \mathrm{mmol} \mathrm{L}^{-1}$ ATP for carrot cell suspension culture. However, since a clear increase in AK activity was observed by decreasing the magnesium sulphate concentration to $12.5 \mathrm{mmol} \mathrm{L}^{-1}$, this was adopted for the new optimized assay for maize AK.

The new optimized hydroxamate assay for AK determination was carried out by combining the stock solutions to a final volume of $500 \mu \mathrm{L}$ and incubating at $35^{\circ} \mathrm{C}$ for a standard period of $60 \mathrm{~min}$, that could be reduced to a minimum of 45 min and a maximum of 120 min. The reaction was stopped with $500 \mu \mathrm{L}$ ferric chloride reagent, mixed and centrifuged for $5 \mathrm{~min}$ and the absorbance of the supernatant read at $505 \mathrm{~nm}$ after using a blank lacking aspartic acid, however, absorbance values lower than 0.05 should be considered with caution.

\section{ACKNOWLEDGEMENTS}

This work was funded by Fundação de Amparo à Pesquisa do Estado de São Paulo (FAPESP - Grants n ${ }^{\circ}$. 98/12461-0 and 01/13216-4) and The British Council. R.A.A. would like to thank CNPq for the fellowship and R.R.F. and A.V. also would like to thanks FAPESP (00/ 05960-2 and 02/09254-0), for the scholarships granted.

\section{REFERENCES}

AARNES, H.; ROGNES, S.E. Threonine-sensitive AK and homoserine dehydrogenase from Pisum sativum. Phytochemistry v.13, p.2717-2724, 1974.

AZEVEDO, R.A. Analysis of the aspartic acid metabolic pathway using mutant genes. Amino Acids, v.22, p.217-230, 2002.

AZEVEDO, R.A.; ARRUDA, P.; TURNER, W.L.; LEA, P.J. The biosynthesis and metabolism of the aspartate derived amino acids in higher plants. Phytochemistry, v.46, p.395-419, 1997.

AZEVEDO, R.A.; DAMERVAL, C.; LANDRY, J.; LEA, P.J.; BELLATO, C.M.; MEINHARDT, L.W.; LE GUILLOUX, M.; DELHAYE, S.; TOTO, A.A.; GAZIOLA, S.A.; BERDEJO, B.D.A. Regulation of maize lysine metabolism and endosperm protein synthesis by opaque and floury mutations. European Journal of Biochemistry, v.270, p.4898-4908, 2003.
AZEVEDO, R.A.; DAMERVAL, C.; LEA, P.J.; LANDRY, J.; BELLATO, C.M.; MEINHARDT, L.W.; LE GUILLOUX, M.; DELHAYE, S.; TORO, A.A.; GAZIOLA, S.A.; VARISI, V.A.; GRATÃO, P.L. Genetic control of lysine metabolism in maize endosperm mutants. Functional Plant Biology, v.31, p.339-348, 2004a.

AZEVEDO, R.A.; LEA, P.J.; DAMERVAL, C.; LANDRY, J.; BELLATO, C.M.; MEINHARDT, L.W.; LE GUILLOUX, M.; DELHAYE, S.; VARISI, V.A.; GAZIOLA, S.A.; GRATÃO, P.L.; TOTO, A.A. Regulation of lysine metabolism and endosperm protein synthesis by the opaque-5 and opaque-7 maize mutants. Journal of Agricultural and Food Chemistry, v.52, p.4865-4871, $2004 \mathrm{~b}$.

AZEVEDO, R.A.; LEA, P.J. Lysine metabolism in higher plants. Amino Acids, v.20, p.261-279, 2001.

BONNER, P.L.R.; LEA, P.J. Enzymes of lysine synthesis. In: LEA, P.J. (Ed.) Methods in plant biochemistry: Enzymes of primary metabolism. London: Academic Press, 1990. v.3, p.297-315.

BRADFORD, M.M. A rapid and sensitive method for the quantitation of microgram quantities of protein utilizing the principle of protein-dye binding. Analytical Biochemistry, v.72, p.248-254, 1976.

CHESHIRE, R.M.; MIFLIN, B.J. The control of lysine biosynthesis in maize. Phytochemistry, v.14, p.695-698, 1975.

DAVIES, H.M.; MIFLIN, B.J. Aspartate kinase from carrot cell suspension culture. Plant Science Letters, v.9, p.323-332, 1977.

DOTSON, S.B.; SOMERS, D.A.; GENGENBACH, B.G. Purification and characterization of lysine-sensitive aspartate kinase from maize cell suspension cultures. Plant Physiology, v.91, p.1602-1608, 1989.

DOTSON, S.B.; SOMERS, D.A.; GENGENBACH, B.G. Kinetic studies of two lysine-sensitive aspartate kinase purified from maize cell cultures. Plant Physiology, v.93, p.98-104, 1990.

FERREIRA, R.R.; VENDEMIATTI, A.; MEINHARDT, L.W.; LEA, P.J.; AZEVEDO, R.A. Isolation of enzymes involved in threonine biosynthesis from sorghum seeds. Brazilian Journal of Plant Physiology, v.16, p.95-104, 2004.

FORNAZIER, R.F.; AZEVEDO, R.A.; FERREIRA, R.R.; VARISI, V.A. Lysine catabolism: flow, metabolic role and regulation. Brazilian Journal of Plant Physiology, v.15, p.9-18, 2003.

HELM, C.V.; DE FRANCISCO, A.; GAZIOLA, S.A.; FORNAZIER, R.F.; POMPEU, G.B.; AZEVEDO, R.A. Hull-less barley varieties: storage proteins and amino acid distribution in relation to nutritional quality. Food Biotechnology, v.18, p.327-341, 2004.

LEFÈVRE, A.; CONSOLI, L.; GAZIOLA, S.A.; PELLEGRINO, A.P.; AZEVEDO, R.A.; DAMERVAL, C. Dissecting the opaque-2 regulatory network using transcriptome and proteome approaches along with enzyme activity measurements. Scientia Agricola, v.59, p.407-414, 2002.

MAUAD, M.; CRUSCIOL, C.A.C.; GRASSI FILHO, H.; CORRÊA, J.C. Nitrogen and silicon fertilization of upland rice. Scientia Agricola, v.60, p.761-765, 2003.

MEDICI, L.O.; AZEVEDO, R.A.; SMITH, R.J.; LEA, P.J. The influence of nitrogen supply on antioxidant enzymes in plant roots. Functional Plant Biology, v.31, p.1-9, 2004.

MUEHLBAUER, G.J.; SOMERS, D.A.; MATTHEWS, B.F.; GENGENBACH, B.G. Molecular genetics of the maize (Zea-mays L) aspartate kinase homoserine dehydrogenase gene family. Plant Physiology, v.106, p.1303-1312, 1994.

PINTO, L.R.; VIEIRA, M.L.C.; SOUZA JR., C.L.; SILVA, R.M. Isoenzymatic variability in tropical maize populations under reciprocal recurrent selection. Scientia Agricola, v.60, p.291-297, 2003.

PRIOLI, L.M.; SONDAHL, M.R. Plant-regeneration and recovery of fertile plants from protoplasts of maize (Zea mays $L$ ). Bio-Technology, v.7, p.589-594, 1989.

SHEWRY, P.R.; MIFLIN, B.J. Properties and regulation of AK from barley seedlings. Plant Physiology, v.59, p.69-73, 1977.

TORO, A.A.; MEDICI, L.O.; SODEK, L.; LEA, P.J.; AZEVEDO, R.A. Distribution of soluble amino acids in maize endosperm mutants. Scientia Agricola, v.60, p.91-96, 2003.

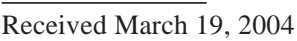

Accepted December 13, 2004 